\title{
A média hatása a világproblémákra
}

(A tematizálás és a közvélemény alakulásának lehetséges viszonyrendszere)

\section{Szerzői információ:}

S z é k e ly Móze s

Fizikus, 1994-ben végzett az ELTE TTK-n, diplomamunkáját a statisztikus mechanika matematikai alapjai témából írta; 2003-ban az ELTE Szociálpszichológia szakán doktorált. 2003-tổl az ELTE Tùdományszervezési, Pályázati és Innovációs Központ vezetổje és a MTA Kommunikációelméleti Kutatócsoport tudományos munkatársa.

Egyéb megbízások, választott funkciók és szakmai tevékenységek: 2004- Nemzeti Fejlesztési Hivatal (vezetési tanácsadó); 2003- Komfort Országos Egészségpénztár (az Igazgatótanács elnöke); 2002-Környezeti Nevelési és Kommunikációs Programiroda (felsôoktatási és vezetési tanácsadó); 2000- ELTE kutatásvezetô (Világproblémák; 'Cultural Creative' Hungarian Survey); 1996- ELTE oktató (Társadalmi programok értékelése; Nemzetközi viszonyok pszichológiája; Világproblémák szociálpszichológiája; Gazdaságpszichológia).

Email mozes@ludens.elte.hu

Így hivatkozzon erre a cikkre:

Székely Mózes. „A média hatása a világproblémákra”.

Információs Társadalom IV, 3-4. szám (2004): 88-97.

https://dx.doi.org/10.22503/inftars.IV.2004.3-4.13

A folyóiratban közölt müvek

a Creative Commons Nevezd meg! - Ne add el! - Így add tovább! 4.0

Nemzetközi Licenc feltételeinek megfelelóen használhatók. 
S z é ke ly Móze s

A média hatása a világprblémákra

A tematizálás és a közvélemény alakulásának lehetséges viszonyrendszere

Elolvasva Sükösd Miklósnak az Információs Társadalom 2003/3-4. számában megjelent, ,Totális medialitás és ökocídium. Mediatizáció és fogyasztói társadalom: ökológiai médiakritika" címú címû cikkét és a beérkezett összes reagálást, arra jutottam, hogy hozzászólásként megrövidítve, átszerkesztve elküldöm a Jel-Kép egy korábbi számában megjelent, a tárgyhoz kapcsolódó munkámat. ${ }^{\prime}$

Kérdés, mi lehet ennek a hozzáadott értéke. Egyrészt kiegészítheti a témában felmerült hivatkozásokat azokkal a (szociál)pszichológiai megközelítésekkel, amelyeket a vitába bekapcsolódott szerzők nem említettek és kevéssé ismerhetnek. Másrészt a hitviták, az értékütközések, a paradigmatikus meg nem értés és a zsigeri adokkapok mellett a résztvevők többsége számára feltehetôleg fontos kiindulási tények továbbgondolásának is teret adhat. Harmadrészt a kutatások folytatásához nyújthat támpontokat, amennyiben amennyiben - gondolom - többen szívesen továbbhaladnánk a jelenségkör megértésében. Remélem, írásom hozzájárulhat a vita előrehaladásához.

A média kulcsszerepet játszik abban, hogy mi kerülhet fel a közgondolkodás napirendjére, mely problémák fontosak, s a tömegkommunikációs iparban dolgozók határozzák meg, hogyan kell értelmezni az egyes eseményeket. Egyszerre gyakorol hatást a közvélemény számára elérhetố témakörökre és a róluk kialakuló attitûdökre. Kiemelten igaz ez a világproblémák - köztük a környezeti problémák -- észlelésére és felidézésére, amelyek sokszor távoli helyekhez, emberekhez és eseményekhez kötôdnek. Jelen tanulmányomban a média által közvetített problémakörök előfordulási gyakoriságait vetem össze a felnőtt magyar lakosság reprezentatív mintáján kapott kategóriacsoportok említési gyakoriságaival.

\section{A média és a közvélemény: a témaválasztás és a megfogalmazás}

A közvélekedés alakulásában a médiumok hatása a régóta ismert és vizsgált jelenségek közé tartozik. Nyolcvan évvel ezelôtt Walter Lippmann az elsôk között hívta fel a figyelmet arra, hogy a sajtószabadság társadalmaiban az újságíróknak meghatározó szerep jut a közvélemény homlokterébe kerülő témák kiválasztásában. Különösen igaz ez a mindennapok megszokott közegétôl és gondjaitól távol esô témakörök, például a világproblémák esetében. Az emberiség egészét érintô kérdéskörök megismerése éppúgy a médián keresztül képzelhető el, mint ahogy az összetett jelenségkörök értelmezése is többnyire a tömegtájékoztatás feladata és felelőssége. Ez utób-

\footnotetext{
${ }^{1}$ A jelen írás eredeti változata a Jel-Kép 2003/4. számában (27-45.o.) jelent meg.
} 
bit szinte létrejötte óta számonkérik a médiumoktól, ahogy Lippmann fogalmaz a a sajtó szerinte kifejezetten szeszélyes tematizálásáról: „olyan, mint a fényszóró nyugtalanul imbolygó sugara, amely hol az egyik, hol pedig a másik eseményt emeli ki a sötétből" (Lippmann, 1922).

Az utóbbi évtizedekben egyre nő a média által felvállalt témák és a közvélekedés összefüggéseivel foglalkozó kutatások száma. A kezdetek óta nyilvánvaló, hogy bár a szerkesztôk elhitethetik magukkal, hogy csupán a közönség igényeinek igyekeznek megfelelni, valójában irányítják a közvélemény figyelmét, és meghatározzák, miről gondolkodjanak és beszéljenek az emberek (Cohen, 1963). Már az elsó empirikus vizsgálatokban részletesen elemezték a tematizálás funkcióit (McCombs - Shaw, 1972), a vezetố hírek és a világról alkotott nézetrendszerek kapcsolatát (Erbring Goldenberg - Miller, 1980). A tömegkommunikáció napirendet meghatározó szerepének alapeseteitôl (Rogers - Dearing, 1988), a közgondolkodás intenzitástól és változatosságtól függő témaészlelésének ingerküszöbén át (Neuman, 1990; Brosius Kepplinger, 1990) jutunk el a média közvélekedést érintő torzításainak részletes öszszefoglalásáig (lásd pl. Kinder - Sears, 1985). A legradikálisabb nézốpontok pedig miközben nem kérdőjelezik meg a magasan képzett, kiválóan teljesítő és becsületes újságírók professzionalizmusát - úgy vélik, hogy elsősorban a médiumok tulajdonosai között meghatározó nagyvállalatok és állami szereplốk érdekei határozzák meg, mi látható, hallható vagy olvasható a nagyközönség számára (Chomsky, 1989; 1999).

A közvélemény formálásában a közbeszéd napirendjével azonos jelentőségűek az egyes témakörök megfogalmazásai, és fogalmi keretei. Ahogy a tömegkommunikációban elsốrendû a tárgyalt esemény megszövegezése, ez éppúgy központi fontosságú a jelenség megítélésében is, miként azt a választás pszichológiáját elemezve Tversky és Kahneman több mint két évtizede részletesen kifejtette. A megfogalmazás egyaránt kiemeli a lényeget és meghatározza a társadalmi viták lehetséges dimenzióit (Gamson - Modigliani, 1987), miközben leegyszerúsíti a bonyolult és sokrétû problémákat. Például egy politikai vita lefordítása a feketék és fehérek közötti megkülönböztetés, a faji diszkrimináció nyelvére teljesen más véleményeket vált ki, mintha ugyanezt pusztán gazdasági kérdésként kezelnék (Kinder - Sanders, 1990). Az egyre növekvő számú empirikus vizsgálat igazolja, hogy a közvélemény alakulása nyilvánvalóan és szisztematikusan függ a véleményformálók által használt fogalmi keretektôl, a hangsúlyozott és a figyelmen kívül hagyott megközelítésmódoktól (lásd pl. Nelson - Kinder, 1996). A közgondolkodásban tárgyalt témakörök megfogalmazásai így az elitcsoportok retorikai fegyverének tekinthetôk, amelyekkel érdekeiket és ideológiájukat támaszthatják alá (Kinder, 1998).

\section{Világproblémák és média: mediatizált kommunikáció és kiteriesztett szolidaritás}

A világproblémák, mint távoli jelenségek elsősorban mediatizált csatornákon keresztül ismerhetôk meg. A személyes tapasztalati keretekbe a tömegkommunikáción keresztül illeszkednek be, így kap értelmet a globális világ, így tudatosodnak és válnak érzelmileg felfoghatóvá a világesemények (Giddens, 1991). A globális problémák tudatosulása a médiának köszönhető́en tudatosulása segítheti elő a világgondok meg- 
oldásáért érzett morális felelősségvállalás kialakulását, a távoli népek sorsa iránti érzékenység, a tág értelemben vett „szolidáris individuum” megjelenését a mindennapokban (Beck, 1992; Thompson, 1995; Berking, 1996). Miközben egyre növekvố számú kutatás foglalkozik a médiumok által közvetített, főként a hírmúsorokból megszerezhetô „közös tudás” fogyasztásával, addig viszonylag kevés szó esik a kommunikációnak a befogadóra gyakorolt hatásáról (Cottle, 1998).

A környezeti problémakör esetében találunk néhány kivételt. Allan Mazur tartalomelemzést végzett az Egyesült Államokban elsődleges hírforrásnak tekintett The New York Times 1987-1996 közötti környezeti vonatkozású híranyagaiban. Egyik meglepő következtetése, hogy a média által felvetett globális témák gyakoriságai alig kötődnek az adott terület tudományos felismeréseihez, vagy a környezet tényleges fizikai álapotának változásaihoz. Másrészt úgy véli, hogy a híradások mennyisége, s főként azok leegyszerûsített képeinek ismétlései meghatározó befolyást gyakorolnak a közgondolkodásban kimutatható hangsúlyokra. Amikor a 80 -as évek végén az ökológiai kérdésekről növekvő számú információt juttatott a média az emberekhez, akkor a közvéleménykutatásokban is többen számoltak be ezek fontosságáról, míg a 90-es évek elején egy éppen fordított tendencia írható lefigyelhető meg (Mazur, 1998). Hasonló összefüggést állapítottak meg Hongkongban is. Az írott sajtó környezeti problémákkal foglalkozó cikkeinek száma és a hongkongiak környezeti tudatosodása (a szervezeti közremûködés, a híradásokra fordított figyelem és a kormányzattal szembeni elvárások) az 1983-1995 közötti időszak elején együtt emelkedtek, majd folyamatosan vesztettek jelentőségükből (Chan, 1999).

Egy másik például Louise Phillips diskurzus-elemzése szolgál. Fiatal párokkal Dániában felvett interjúi alapján három különbözô közlési keretet különített el. Az ökológikus ökológiai diskurzusban a vizsgálati személyek felelős környezetkímélő viselkedést mutattak. A tipikus fogyasztói diskurzus arra ösztönöz, hogy minden cselekvési szándék fogyasztói magatartásban öltsön testet. A mindenapok kényszereinek diskurzusai az idő szorításáról, az anyagi korlátokról és a személyes készségek hiányáról szólnak. A média-tapasztalatokból építkező ökológikus ökológiai elköteleződés a mindennapok közlésvilágába ágyazódva többnyire fogyasztói döntésekben ölt testet. A globális problémák közvetett, kizárólag a médiumokon át feltáruló valósága egyértelmúen elkülönül a megtapasztalt hétköznapi létezéstôl, s így az egyes ember csak korlátozott szerepet érez magáénak a súlyos társadalmi gondok kezelésében (Phillips, 2000).

\section{Közvélemény és világproblémák: környezet, szegénység és há- borúk}

A világproblémákkal kapcsolatos vélekedéseket 2000 januárjában mértük fel az ország felnőtt lakosságát reprezentáló 1000 fős mintán. A vizsgálat itt elemzendő elsố szakaszában előstrukturálás nélküli, nyitott kérdéseket tettünk fel, amelyekben a világ legátfogóbb problémáit kerestük, rangsorolás és a válasszámok korlátozása nélkül. Az eredmények azt igazolták, hogy az ezredfordulón a mindennapok gondjai mellett jut időnk foglalkozni az emberiség nagy gondjaival is. A megkérdezettek $95,1 \%$-a önállóan meg tud nevezni globális problémákat - kétharmaduk egynél többet is - , s 
a válaszok szokatlan tartalmi gazdagságot mutatnak, a témakörök megkapóan széles körét ölelik fel. (A tartalomelemzés és a statisztikai feldolgozás részleteiről, illetve a környezettel kapcsolatos eredményekrôl lásd Székely 2002a és 2002b.)

A teljes mintán a környezet $(35,0 \%)$, a szegénység $(32,4 \%)$ és a háborúk $(30,6 \%)$ problémakategóriáit említették a legtöbben, amit a megélhetési problémák és a munkanélküliség $(21,1 \%)$, majd a betegségek és az éhezés (16,1\% és 14,3\%) kérdéskörei követtek. Az egyes rétegek gyakorisági rangsorai (néhány túlzottan kis elemszámú részmintától eltekintve) gyakorisági rangsorai - a szignifikánsan különböző csoportokra vonatkoztatva - megegyeznek egymással, azaz az egyes problémaköröket lényegében azonos arányban hangzottak elemlítették a nők és férfiak, az idősebbek és fiatalabbak, a különbözóképpen iskolázottak és az eltérố lakóhelyú válaszolók között. Példaként a Környezetszennyezés és pusztitás, illetve a Politikai és gazdasági problémák kategóriacsoportjainak legfontosabb jellemzóit mutatjuk be a rétegzettségben fellelhetô - az egységes képet néhány ponton megbontó - szignifikáns differenciákon keresztül.

Reprezentatív mintánkban a világ problémáinak tárgyalása a válaszok relatív többségéből a környezet közismert problémaköreit hívta elő (bár a szegénységtôl és háborúktól szignifikánsan nem különbözố mértékben). A nem és a lakóhely szerinti szociológiai rétegeiben rétegekben gyakorlatilag egyforma arányban vetôdik vetôdött fel ez a problémakör. Az életkorral viszont függvényszerű (lineáris) kapcsolat volt kimutatható ki: a fiatalabbak lényegesen többször említik említették a környezet ügyét világproblémaként, mint az idősebbek. A 60 év felettiek átlaga 27,6\%, a 40 év alattiaké 41,3\% (a két csoport eltérése a náluk fiatalabbaktól, illetve idősebbektôl szignifikáns). Hasonlóképp szoros, és a szociológiai változók esetében kiemelkedően erôs a lineáris összefüggés a környezetszennyezés és az iskolázottság között (a változó varianciájának 3,8\%-át magyarázza a tanultság). A gyakoriságok közötti különbségeket jól jellemzi a legfeljebb alapfokon iskolázottaknál mért 22,4\%-os előfordulási arány szembeállítása a diplomások 53,3\%-os hasonló arányszámával. Összefoglalva az 1960 után született fiatalabbak, és a minél magasabb (de kiemelten a felsőfokú) végzettségúek számára jelentenek egyet a világ problémái a környezeti problémákkal.

A megkérdezettek egytizede általános politikai és gazdasági természetú gondokat nevezett meg világproblémaként. Nem és iskolázottság szerint nincsenek jelentôs különbségek. A városiak számára ez kis mértékben jelentôsebbnek tûnik: 11,7\%os arányban említették, míg a községekben lakók csupán 7,1\%-ban - mintha az utóbbiak árnyalatnyival nagyobb távolságot tudnának tartani a politikai jellegư témáktól. Az életkori csoportok között a 40 év alattiak némileg ritkábban említik ezt (7,2\%-uk, szemben a többiek 12,2\%-ával), míg a legtöbbször a 40-60 év közöttiek vetik fel (átlagosan 13,8\%-ban). A 18-19 évesek 10,0\%-os aránya viszont közel kétszerese a huszonévesek 5,3\%-os arányának, ami ugyan a kis elemszám és a legfiatalabbak kis létszámú mintája miatt nem szignifikáns, de jelzés értékủ az általános politikai-gazdasági kérdéskörök életkori dinamizmusát illetően jelzésértékű. Összességében tehát a politikai és gazdasági problémák esetében a nagyjából azonos eloszlást mutató szociológiai rétegek közül finoman kiemelkednek ki a középkorú és városlakó felnôttek. 


\section{A hírmüsorokban megielenő problémakörök: politika, gazdaság és bűnözés}

A világproblémák asszociatív említéseit elemezve joggal vetôdik fel a kérdés, hogy vajon a társadalmi rétegeken átívelő egyöntetû gyakoriságok - s a mindemellett még durva eszközökkel is kitapintható, egyszersmind a felszínességre rácáfoló árnyalatnyi különbözőségek - milyen közös forrás(ok)ból táplálkozhatnak. Vajon nem egy lényegében azonos információforrás határozza meg az alacsonyan és magasan képzettek, a fővárosiak és vidékiek, a fiatalok és idősek számára lényegében egyforma válaszmintázatokat? Számos vizsgálat igazolta például, hogy a népesség minél nagyobb aránya minél több időt tölt a televízió képernyője előtt, a valóságról alkotott felfogásuk annál inkább azonossá válik, legyőzve minden más réteg- vagy csoportspecifikus hatást (Gerbner et al., 1986). A fentebb bemutatott vizsgálatban nem volt módunk a megkérdezettek véleményének hátterérôl tudakozódni, így csak utólagosan kísérelhettük meg a lehetséges okok feltárását. A legvalószínúbb közös befolyásoló tényezôként szinte természetes módon a média adódik, hiszen sem az oktatásban, sem a hétköznapokban, illetve a munkahelyeken nem találunk a lakosság többsége számára elérhető információkat, $s$ amit mégis, azok döntô többségükben szintén a médiából erednek.

Az Országos Rádió és Televízió Testület Irodája a vizsgálatunk időszakában is folyamatos tartalomelemzést végzett az elektronikus média hírmúsoraiban. Tekintettel arra, hogy a távoli világ problémáinak problémáiról a legszélesebb rétegekhez eljutó ismeretei ismeretek feltehetően leginkább ezen ezekből a forrásokból származhatnak, így a legnézettebb és leghallgatottabb híradások témaköreit véltük célszerûnek összevetni saját eredményeinkkel. A hírek kiválasztását indokolja továbbá, hogy főmműsoridőben - néhány kivételtől eltekintve - csak ezek tekinthetők „,komoly aktuális" programoknak, még a közszolgálati csatornákon is sokan látják ezeket, ha pedig a nézettségi mutatókban élenjáró kereskedelmi médiákat vizsgáljuk, ott ebben az idősávban a híradásokon kívül szinte minden program a könnyứ szórakozás kategóriájába tartozik (Terestyéni, 2001). Feltételeztük, hogy a média tematizálása hatással van a megkérdezettek asszociatív véleményére, leegyszerúsítve: minél gyakrabban foglalkozik a televízió vagy a rádió főmúsoridőben egy-egy problémakörrel, az annál nagyobb valószínûséggel hívható elő az egyébként többségében tévét néző és híreket hallgató interjúalanyokból egy kérdőíves felmérés során.

Az ORTT Mứsorelemzố Osztálya rendelkezésünkre bocsájtotta a világproblémákról szóló kérdőívünk felvételét megelőző 3 három átlagosnak tekinthető hónap, 1999 szeptember, október ése és novembere közötti időszak adatait. A tartalomelemzés eredeti szempontjai természetszerúleg nem egyeztek pontosan az általunk kitúzött célokkal. A músorfolyam tartalmi feldolgozása elsősorban a magyar vonatkozású eseményekre koncentrált, így a minket érdeklő nemzetközi hírek többsége sajnálatosan kimaradt a részletes témakörök szerinti besorolásból. A Magyarországot érintő mưsoregységekben megjelenő témák gyakoriságai azonban durva közelítésben támpontul szolgálhatnak az összevetéshez. Ez részben a szerkesztők általános (a bemutatni kívánt jelenségkörökre, és nem azok specifikus vonatkoztatási környezetére jellemző, ezáltal a nemzetközi és a hazai hírekre egyaránt érvényes) témaválasztási szempontjaival indokolható, részben azzal, hogy a kérdőíves vizsgálat interjúalanyai 
számára sem választódnak el mindenkor élesen a múltbeli, gyakran hallott témakörök konkrét keretei.

Elemzésünkbe a közszolgálati csatornák közül az MTV1 esti (19.15) Híradóját, a Kossuth Rádió Reggeli (6.00-7.00), Déli (12.00) és Esti (18.00) Krónikáját, a kereskedelmi adásokból a TV2 Tények (18.30), az RTL Klub Híradó (18.30), valamint a Danubius, illetve a Sláger Rádió Reggeli hírek (kb. 6.30) c. mûsorait vontuk be. A hazai vonatkozású hírekre leszúkített minta - egységes kódutasítás alapján csaknem száz előre megadott témalista alapján beazonosított és kódolt - 6855 műsoregységének 10.604 témakörét soroltuk be a felmérésünkben alkalmazotthoz igazított kategóriarendszerbe. Bár az egyes csatornák kódolt műsoregységeinek száma, továbbá a mûsoregységenként megkülönböztethető témakörök mennyisége némileg eltérő, azonban ez a témák gyakorisági sorrendjét - végső soron - nem befolyásolja.

Feltûnő, hogy mind a televízió, mind a rádió közszolgálati és kereskedelmi csatornáinak hírmúsoraiban lényegében azonos gyakorisággal fordulnak elő az egyes témakörök. A témacsoportok gyakorisági sorrendjeinek szignifikáns korrelációs együtthatói minden egyes csatorna, illetve médiumtípus összevetésében rendkívül magasak, 0,862 és 0,995 közé esnek. Az ezredforduló hazai elektronikus tömegtájékoztatásában magasan kiemelkedve minden második hírben szerepet kap a politika $(52,5 \%)$, s a hírek több mint harmada gazdasági vonatkozású információkról szól (35,9\%). Ehhez képest jelentôsen lemaradva a híregységek ötöde kapcsolódik a bünözéshez (20,4\%), s némileg kevesebb esetben tárgyalnak a megélhetéssel (árakkal, bérekkel, munkanélküliséggel) foglalkozó jelenségeket $(14,0)$ ). Számottevő még az oktatás, a tudomány, és a kultúra megjelenése $(8,5 \%)$, de a többi tématerület (pl. szociálpolitika, környezetvédelem, kábítószerek, egészségügy) egyike sem gyakoribb a hírmûsorokban $5 \%$-nál.

Az eredmények több ponton egybecsengenek a televíziós hírműsorok korábbi hasonló tartalomelemzéseken alapuló, de átfogó kategóriák helyett egyes kiemelt témakörökre koncentráló - vizsgálatainak eredményeivel. Egyrészt a közszolgálati és a kereskedelmi programfolyamok egészének különbözőségei ellenére a hírstruktúrákban globálisan hasonló képet kaptak valamennyi csatorna napirendre vett témaköreit illetốen. Másrészt - legalábbis a kereskedelmi tévék elindulását követốen, így már 1997 végén is - a konkrét politikai tartalmak (pl. pártok versengése, NATO- vagy EU-csatlakozás, korrupció stb.) a bünözés és közbiztonság, illetve a megélhetéssel és gazdasági kérdésekkel foglalkozó músoregységek uralták a televíziók hírmûsorait (Terestyéni, 1998). A közszolgálati és kereskedelmi csatornák témastruktúrájának - vizsgálatunkkal lényegében azonos időszakban végzett - részletesebb összehasonlításai is hasonló következtetésekre jutottak: az egyes témakörök arányai különbözőek, de gyakorisági sorrendjeik megegyeznek, s mindkét médiatípusnál a „katasztrófa-tematika” mindkét médiatípusnál megelőzi a politikai, illetve a gazdasági híreket, miként mindhárom lényegesen többször fordul elő, mint az egyes társadalompolitikai témák - az oktatás, az egészségügy, a szociálpolitika vagy a környezet (Nyilas, 2000). 


\section{Média - világprobléma - közvélemény}

A felnőtt magyar lakosság által legfontosabbnak tartott problémakategóriák és az elektronikus tömegtájékoztatás „kedvenc” témakörei meglehetősen távol esnek egymástól. Az alábbi táblázat elsố két oszlopában egymás mellé helyeztük az összehasonlítható kategóriacsoportok gyakorisági sorrendjeit, s látható, hogy az elsố három helyen a társadalmi kérdések teljesen eltérô jelenségköreit találhatjuk. Talán a megélhetés (az árak, a bérek és a munkanélküliség) az egyetlen nagyjából azonos súllyal kezelt terület a médiában és a közgondolkodásban. Különösen figyelemre méltó, hogy az itt nem elemzett nemzetközi vonatkozású hírekben is túlsúlyos politikai és gazdasági témák (kiegészülve a bűnözéssel, terrorizmussal és katasztrófákkal) szinte mindent átható előfordulási aránya ellenére a közvélemény ettốl teljesen eltérô prioritásokat fogalmaz meg: a hazai médiában szinte meg sem jelenő éhezés és népesedés (!) problémakörei mellett a környezet, a szegénység, a háborúk és a betegségek ügyeit.

A világproblémák, a médiatémák és a hazai gondok összehasonlítható kategóriacsoportjainak gyakorisági rangsorai

\begin{tabular}{l|l|l|}
$\begin{array}{l}\text { Világproblémák } \\
\text { gyakorisági sora } \\
\text { (nyitott kérdések) }\end{array}$ & $\begin{array}{l}\text { Hírmũsorok témagyakoriságai } \\
\text { (hazai vonatkozású hírek) }\end{array}$ & $\begin{array}{l}\text { Hazai problémák rangsora } \\
\text { (zárt kérdések) }\end{array}$ \\
\hline Környezetszennyezés & Politika és gazdaság & Alkohol, cigaretta, kábítószer \\
\hline Szegénység és egyenlötlenségek & Bünözés & Szegénység és egyenlőtlenségek \\
\hline Háborúk, fegyverkezés & Megélhetés, munkanélküliség & $\begin{array}{l}\text { Környezetszennyezés és } \\
\text { pusztítás }\end{array}$ \\
\hline $\begin{array}{l}\text { Megélhetési problémák, } \\
\text { munkanélküliség }\end{array}$ & Oktatás, kultúra, tudomány & $\begin{array}{l}\text { Egészségtelen életmód, } \\
\text { elkényelmesedés }\end{array}$ \\
\hline Betegségek & Katasztrófák, balesetek & $\begin{array}{l}\text { Járványok, gyógyíthatatlan } \\
\text { betegségek }\end{array}$ \\
\hline Erốszak, búnözés & Szociálpolitika & Etnikai és vallási fanatizmus \\
\hline Politikai és gazdasági problémák & Honvédelem, NATO & Háborúk és fegyverkezés \\
\hline Etnikai és vallási fanatizmus & Drogkérdés & $\begin{array}{l}\text { Túlzott fogyasztás, } \\
\text { értelmetlen túltermelés }\end{array}$ \\
\hline Alkohol, cigaretta, kábítószer & Környezetvédelem & $\begin{array}{l}\text { Kulturális elszigetelốdés, } \\
\text { analfabetizmus }\end{array}$ \\
\hline Egészségtelen életmód & Kisebbségek, menekültek & \\
\hline & Sport & \\
\hline & Egészségügy & \\
\hline
\end{tabular}

Kontrasztosabbá teszi a képet, ha mindezek mellé állítjuk az ugyanezen reprezentatív minta válaszai alapján felállított legjelentôsebb hazai problémák fontossági sorát. Kiderül, hogy például a már említetteken kívül például az itthon legnagyobb társadalmi veszélynek tartott „alkohol, cigaretta és kábítószerek” kérdéskörei aligalig jelennek meg a média központi helyein (a perifériákon se túl gyakran), vagy a szintén joggal jelentôsnek tartott betegségek és az egészségtelen életmód ügye a média egyik legmostohábban kezelt témája. (A hírmúsorok témáinak gyakorisági sorrendjei sem a világproblémák említésével, sem a hazai rangsorral nem mutatnak szignifikáns korrelációt.) 
Tankönyvek, kutatások és összegző tanulmányok sora igazolta már a fogyasztási szokások és a tömegkommunikáció szoros kapcsolatát (lásd pl. Székely, 2003). A marketing, s azon belül a reklámozás ma is egyik leghatékonyabb alkotóeleme az ismétlés, az információk (termékek és márkák) sulykolása. A média komoly (nem kizárólag a szórakoztatást szolgáló) mûsorai közül a híradásokat sugározzák egyedül főidőkben, s az emberek döntô többsége valóban figyeli is ezeket az adásokat. Az itt leggyakoribb témák alapján a politikának és a gazdasági kérdéseknek kellene az vezetô helyeket elfoglalniuk a társadalom problémarangsoraában vezető helyeit elfoglalnia. Egyik irányból a média befolyása miatt, másik irányból pedig azon sokat hangoztatott szerkesztôi állítás alapján, miszerint a mûsorstruktúrát a „köz igényei” alapján állítják össze. Ezzel szemben - egy média-konform, zárt problémalista helyett önálló, nyitott, asszociatív problémafelvetési szituációban - a megkérdezettek a szegénység, a környezet, a háborúk és a betegségek kezelését vélik legfontosabbnak.

Az egyik oldalon tehát a közvélemény a létezés hosszú távon (is) legfontosabb alapkérdéseit - környezet, szegénység, háborúk, éhezés, betegségek - veti fel, a másik oldalon a média a rövid távú politikai és gazdasági problémákat helyezi előtérbe. Röviden: az adóforintokból és hirdetési bevételekből fenntartott tömegtájékoztatás az ügyek jelentôségétôl és súlyosságától teljesen eltérô szempontok szerint tematizál. Gerbner szerint a nézettségi mutatók növeléséért folyó hajsza, a veszteségesség fenyegetésének elkerülése olyan mértékben leszúkíti a televíziós műsorok lehetséges tartalmait, hogy a fogyasztónak lényegében nem maradnak „valódi” alternatívák. Miközben a választható csatornák száma többszörösére nôtt, a programok változatossága drasztikusan csökkent: „az átfogó tartalmi sémák nagy része, mint például a cselekmény szerkezete, a szereposztás, a társadalmi típusok és a szereplők sorsa közös a legtöbb mûsorféleségben és a hírekben is" (Gerbner, 2000:, 23). A hírérték pénzben mért maximalizálása kizárja az igazságossági, a szociális, az etikai, és az esztétikai értékek figyelembe vételét. Nem a közfigyelem a kérdés, hanem a hirdetôknek való megfelelés, vagyis annak elérése, hogy a nézô azt, annyit és úgy fogyasszon, ahogyan azt a reklámok súlykoljáksulykolják.

Az ellentmondások feloldása és megértése további, lényegesen mélyebb és öszszetettebb kutatások megvalósítását elvégzését igényli. Egyrészt érdemes megvizsgálni, hogy a sajtó „önálló hatalmi ág” szerepében egyáltalán elkerülheti-e a hatalomhoz szorosan kötődô politika és gazdaság ennyire túlzottnak tûnő tárgyalását, vagy errôl lemondva épp e kontrolláló funkcióját kényszerülne feladni. Másrészt az is kérdéses, hogy az olyan „felszíni” hatások, mint amit az emberek által kevésbé fontosnak tartott témák napról napra való tárgyalása jelent, vajon milyen mértékben befolyásolják a tömegtájékoztatás fogyasztóinak értékrendjét, attitûdjeit, vélekedéseit és viselkedését a problémakörök felvetésének és rangsorolásának absztrakt területén. Erôforrásaink felhasználása és újraelosztása mindazonáltal épp a keveset tárgyalt témakörökben (egészségügy, környezet, szociálpolitika stb.) jelentôs, s itt egyszerre lenne szükség a társadalom minél hitelesebb tájékoztatására, az egyik oldalon, illetve a „köz véleményének" figyelembe vételére a másikon. 


\section{IRODALOM}

Beck, Ulrich (1991): The risk society. London, Sage.

Berking, H. (1996): Solidary individualism. The moral impact of cultural modernization in late modernity. In Lash, S. - Szerszinsky, B. - Wynne, B. (eds.): Risk, environment and modernity. Towards a new ecology. London, Sage.

Brosius, H. B. - Kepplinger, H. M. (1990): The agenda-setting function of television news. Static and dynamic views. Communication Research, 17: 183-211.

Chan, Kara (1999 summer): The media and environmental issues in Hong Kong 1983-95. International Journal of Public Opinion, 11(2): 135-151.

Chapman, Graham - Kumar, Keval - Fraser, Caroline - Gaber, Ivor (1997): Environmentalism and the mass media. The North-South divide. London, Routledge

Chomsky, Noam (1989): Necessary illusions. Thought control in democratic societies. London, Pluto Press.

Chomsky, Noam (1999): Profit over people. Neoliberalism and global order. New York, Seven Stories Press

Cohen, B. (1963): The press and foreign policy. Princeton, Princeton University Press.

Cottle, S. (1998): Ulrich Beck, „Risk society” and the media. A catastrophic view? European Journal of Communication, 13(1): 5-32.

Erbring, L. - Goldenberg, E. - Miller, A. H. (1980): Frontpage news and real-word cues. Another look at agenda-setting by the media. American Political Science Review, 24: 16-49.

Gamson, W. A. - Modigliani, A. (1987): The changing culture of affirmative action. In Braumgart, R. A. (ed.): Research in political sociology. Greenwich, JAI Press, Vol. 3.: 137-177.

Gerbner, George (2000): A média rejtett üzenete. Budapest: Osiris.

Gerbner, George - Gross, Larry - Morgan, Michael - Signorelli, Nancy (1986): Living with television. The dynamics of the cultivation process. In: Jennings, Bryant - Zillman, Dolf (eds.): Perspectives on media effects. New York: Lawrence Erlbaum.

Giddens, Anthony (1991): Modernity and self-identity. Cambridge, Polity Press.

Kinder, Donald R. (1998): Opinion and action in the realm of politics. In Gilbert, Daniel T. - Fiske, Susan T. - Lindzey, Gardner (eds.): The handbook of social psychology. 4th ed. New York, McGraw-Hill, pp. 778-867.

Kinder, Donald R. - Sanders, L. M. (1990): Mimicking political debate with survey questions. The case of white opinion on affirmative action for blacks. Social Cognition, 8: 73-103.

Kinder, Donald R. - Sears, David O. (1985): Public opinion and political action. In Lindzey, Gardner - Aronson, Elliot (eds.): The handbook of social psychology. 3rd ed. New York, Random House, pp. 659-741.

Lippmann, Walter (1922): Public opinion. New York, Macmillan.

Mazur, Allan (1998 Dec.): Global Environmental Change in the News: 1987-90 vs 1992-6. International Sociology, 13(4): 457-472.

McCombs, M. E. - Shaw, D. L. (1972): The agenda-setting function of the media. Public Opinion Quarterly, 36: 176-187. 
Nelson, T. E. - Kinder, D. R. (1996): Issue frames and group-centrism in American public opinion. Journal of Politics, 58: 1055-1078.

Neuman, W. R. (1990): The threshold of public attention. Public Opinion Quarterly, 54: 159-176.

Nyilas György (2000): Összehasonlító elemzés az MTV1 és a TV2 esti, fômúsoridős híradójáról. Jel-Kép, (4): 59-86

Phillips, Louise (2000 Jun.): Mediated communication and the privatization of public problems. Discourse on ecological risks and political action. European Journal of Communication, 15(2): 171207.

Rogers, E. M. - Dearing, J. W. (1988): Agenda-setting research. Where has it been, where is it going? In Anderson, J. (ed.): Communication yearbook. Newbury Park, Sage, pp. 555-594.

Székely Mózes (2002a): Világproblémák tükröződése világképünkben. Alkalmazott Pszichológia, 4 (2): 5-27.

Székely Mózes (2002b): Globális problémák és a környezet. Szociológiai Szemle, 12 (3): 116-134.

Székely Mózes (2003): A fogyasztói magatartás alapjai. A lélek- és a gazdaságtan alapfeltevései a fogyasztásról. In: Hunyady Gy. - Székely M. (szerk.): Gazdaságpszichológia. Budapest, Osiris.

Terestyéni Tamás (1998): A tévéhíradók kínálata és a közönség. Jel-Kép, (2): 57-67

Terestyéni Tamás (2001): A magyarországi televíziós músorkínálat 2000-ben. JelKép, (1): 42-65.

Thompson, J. (1995): The media and modernity. A social theory of the media. Cambridge, Polity Press. 